Article

\title{
Chemical Profile, Antioxidant and Antibacterial Activities of Achillea moschata Wulfen, an Endemic Species from the Alps
}

Sara Vitalini ${ }^{1, *}$, Moira Madeo ${ }^{2}$, Aldo Tava ${ }^{3}$, Marcello Iriti ${ }^{1}$, Lisa Vallone ${ }^{4}$, Pinarosa Avato ${ }^{5}$, Clementina Elvezia Cocuzza ${ }^{2}$, Paolo Simonetti ${ }^{6}$ and Maria Pia Argentieri ${ }^{5}$

1 Dipartimento di Scienze Agrarie ed Ambientali, Università degli Studi di Milano, via G. Celoria 2, 20133 Milano, Italy; marcello.iriti@unimi.it

2 Dipartimento di Medicina e Chirurgia, Università degli Studi di Milano-Bicocca, Via Cadore 48, 20900 Monza, MB, Italy; moira.madeo@gmail.com (M.M.); clementina.cocuzza@unimib.it (C.E.C.)

3 Consiglio per la Ricerca in Agricoltura e l'Analisi dell'Economia Agraria-Centro di Ricerca per le Produzioni Foraggere e Lattiero Casearie (CREA-FLC), viale Piacenza 29, 26900 Lodi, Italy; aldo.tava@crea.gov.it

4 Dipartimento di Scienze Veterinarie per la Salute, la Produzione Animale e la Sicurezza Alimentare Università degli Studi di Milano, via Grasselli 7, 20137 Milano, Italy; lisa.vallone@unimi.it

5 Dipartimento di Farmacia-Scienze del Farmaco, Università degli Studi di Bari “Aldo Moro", via Orabona 4, 70125 Bari, Italy; pinarosa.avato@uniba.it (P.A.); mariapia.argentieri@uniba.it (M.P.A.)

6 Dipartimento di Scienze per gli Alimenti, la Nutrizione e l'Ambiente, Università degli Studi di Milano, via G. Celoria 2, 20133 Milano, Italy; paolo.simonetti@unimi.it

* Correspondence: sara.vitalini@guest.unimi.it; Tel.: +39-02-5031-6766

Academic Editor: Derek J. McPhee

Received: 10 May 2016; Accepted: 21 June 2016; Published: 25 June 2016

\begin{abstract}
Aerial parts of Achillea moschata Wulfen (Asteraceae) growing wild in the Italian Rhaetian Alps were investigated to describe, for the first time, their phenolic content, as well as to characterize the essential oil. Inspection of the metabolic profile combining HPLC-DAD and ESI-MS/MS data showed that the methanol extract contained glycosylated flavonoids with luteolin and apigenin as the main aglycones. Among them, the major compound was 7-O-glucosyl apigenin. Caffeoyl derivates were other phenolics identified. The essential oil obtained by steam distillation and investigated by GC/FID and GC/MS showed camphor, 1,8-cineole, and bornylacetate as the main constituents. The antioxidant capacity of three different extracts with increasing polarity and of the essential oil was evaluated by employing ABTS + and DPPH. radical scavenging assays. The methanolic extract was the only significantly effective sample against both synthetic radicals. All samples were also tested against Gram-positive (Bacillus cereus, Enterococcus faecalis, Staphylococcus aureus) and Gram-negative (Escherichia coli, Proteus mirabilis, Pseudomonas aeruginosa) bacterial species using the disk diffusion assay. The non-polar extracts (dichloromethane and petroleum ether) and the essential oil possessed a broad spectrum of antimicrobial activity expressed according to inhibition zone diameter (8-24 mm).
\end{abstract}

Keywords: Achillea moschata; alpine medicinal plants; alpine ethnobotany; phenolic acids; flavonoids; essential oil; antimicrobial activity; antiradical activity

\section{Introduction}

The genus Achillea (Asteraceae) includes about 130 flowering and perennial species worldwide-mostly in Europe and temperate areas of Asia-but also in North America and North Africa [1,2]. Achillea moschata Wulfen is one of the 23 species recognized in Italy, where it grows on siliceous rocks, screes and stony pastures, along the Alps from $1800 \mathrm{~m}$ up to $3400 \mathrm{~m}$ a.s.1. [3]. It is a 
herb used in traditional and modern recipes for its aromatic traits and in several remedies-both in human and veterinary medicine-for various ailments, as documented in some alpine ethnobotanical studies (Table 1).

Table 1. Traditional uses of A. moschata as documented in the ethnobotanical reports.

\begin{tabular}{cll}
\hline $\begin{array}{c}\text { Use } \\
\text { Category }\end{array}$ & \multicolumn{1}{c}{ Ailment } & $\begin{array}{c}\text { Preparation and } \\
\text { Administration }\end{array}$ \\
\hline & $\begin{array}{l}\text { Abdominal bloating, colic, cold, cough, dysmenorrhea, } \\
\text { earache, fever, flatulence, gastrointestinal disorders, gout, } \\
\text { headache, hypertension, insomnia, menopausal disorders, } \\
\text { neuralgia, oliguria, poor digestion, skin inflammations, } \\
\text { urinary tract inflammations, vaginitis }\end{array}$ & $\begin{array}{l}\text { Infusion (to drink, to make } \\
\text { compresses); Liqueur; } \\
\text { Ointment (to rub) }\end{array}$ \\
\hline $\begin{array}{c}\text { Veterinary } \\
\text { medicine }\end{array}$ & Digestion and skin inflammations (cows and calves) & $\begin{array}{l}\text { Infusion (to drink, to } \\
\text { make compresses) }\end{array}$ \\
\hline Food & Flavouring of typical dishes, soups, desserts, grappa, liqueurs, spicing cheese \\
\hline
\end{tabular}

Despite its long tradition of collection and use, A. moschata has been poorly studied to date. Scientific reports on this plant are very few and essentially limited to germination, altitudinal adaptation and chemosystematics [12-14]. The oil volatile composition was characterized more than 20 years ago $[15,16]$. Therefore, the aim of the present work was the re-investigation of the essential oil composition and the characterization, for the first time, of the phenolic constituents in the aerial parts. In vitro antioxidant and antibacterial activities of both the essential oil and of plant extracts were also measured.

\section{Results and Discussion}

\subsection{Characterization of the Essential Oil}

The essential oil content of $A$. moschata obtained by steam distillation from the dried aerial parts of the plant was quantified as $0.81 \%$, which was then analyzed by GC/FID and GC/MS. The constituents are reported in Table 2, wherein they are listed in ascending order of their retention indices (RIs) on a DB-5 column. A total of 40 components were identified, representing $94.36 \%$ of the oil.

Several compounds were detected belonging to different chemical classes, with monoterpenes and sesquiterpenes identified as the most abundant constituents. A series of unknown compounds were tentatively identified by comparing their MS spectra with those of known compounds.

Monoterpenes made up $81.80 \%$ of the total oil, with oxygenated monoterpenes and monoterpene hydrocarbons detected at $68.44 \%$ and $23.36 \%$, respectively. Sesquiterpenes were found in lesser amounts than monoterpenes, and represented $7.25 \%$ of the sample. Oxigenated sesquiterpenes were the most abundant of this class of constituents, representing $5.62 \%$ of the total oil. Camphor was found to be the major constituent (27.16\% of the oil,) followed by 1,8-cineole (10.69\%) and bornylacetate $(6.21 \%)$.

Other constituents detected in relatively high amounts were the monoterpenes: cis- and trans-thujone (4.78 and $4.82 \%$, respectively), borneol $(4.77 \%)$, cis-sabinene hydrate $(4.28 \%)$ and camphene $(3.82 \%)$. Our data were in agreement with those available from the literature $[15,16]$ although some differences in the quantitative composition of the oil were observed, likely due to the different origin of the plant material under study. 
Table 2. Percentage composition of essential oil from A. moschata.

\begin{tabular}{|c|c|c|c|c|}
\hline$\#$ & Compound & $\mathrm{RI}^{\mathrm{a}}$ & $\mathbf{R I}^{b}$ & $\%$ \\
\hline 1 & santolina triene & 902 & 906 & 0.51 \\
\hline 2 & tricyclene & 916 & 921 & 0.24 \\
\hline 3 & artemisia triene & 923 & 923 & 0.58 \\
\hline 4 & $\alpha$-thujene & 928 & 924 & 1.38 \\
\hline 5 & camphene & 943 & 946 & 3.82 \\
\hline 6 & sabinene & 968 & 969 & 1.83 \\
\hline 7 & $\beta$-pinene & 971 & 974 & 0.84 \\
\hline 8 & 1,8-dehydrocineole & 986 & 988 & 0.03 \\
\hline 9 & myrcene & 992 & 988 & 2.23 \\
\hline 10 & $\alpha$-terpinene & 1013 & 1013 & 0.10 \\
\hline 11 & p-cymene & 1021 & 1020 & 1.30 \\
\hline 12 & 1,8-cineole & 1028 & 1026 & 10.69 \\
\hline 13 & $\gamma$-terpinene & 1055 & 1054 & 0.53 \\
\hline 14 & cis-sabinene hydrate & 1067 & 1065 & 4.28 \\
\hline 15 & trans-sabinene hydrate & 1097 & 1098 & 0.88 \\
\hline 16 & cis-tujone & 1102 & 1101 & 4.78 \\
\hline 17 & isovaleric acid 2-methylbutyl ester & 1109 & 1103 & 0.20 \\
\hline 18 & trans-tujone & 1114 & 1112 & 4.82 \\
\hline 19 & chrysantenone & 1117 & 1124 & 1.43 \\
\hline 20 & camphor & 1142 & 1141 & 27.16 \\
\hline 21 & pinocarvone & 1157 & 1160 & 0.31 \\
\hline 22 & borneol & 1167 & 1165 & 4.77 \\
\hline 23 & terpinen-4-ol & 1176 & 1177 & 1.26 \\
\hline 24 & $\alpha$-terpineol & 1191 & 1186 & 1.43 \\
\hline 25 & trans-piperitol & 1205 & 1207 & 0.02 \\
\hline 26 & bornylacetate & 1280 & 1287 & 6.21 \\
\hline 27 & thymol & 1289 & 1289 & 0.26 \\
\hline 28 & carvacrol & 1297 & 1298 & 0.11 \\
\hline 29 & $\beta$-caryophyllene & 1412 & 1419 & 1.38 \\
\hline 30 & sesquicineole & 1508 & 1515 & 1.31 \\
\hline 31 & sesquiterpene hydrocarbon $\mathrm{C}_{15} \mathrm{H}_{24} \mathrm{MW}=204$ & 1558 & - & 0.25 \\
\hline 32 & oxigenated sesquiterpene $\mathrm{C}_{15} \mathrm{H}_{22} \mathrm{O} \mathrm{MW}=218$ & 1565 & - & 0.37 \\
\hline 33 & oxigenated sesquiterpene $\mathrm{C}_{15} \mathrm{H}_{26} \mathrm{O} \mathrm{MW}=222$ & 1569 & - & 0.15 \\
\hline 34 & caryophyllene oxide & 1573 & 1582 & 1.00 \\
\hline 35 & oxigenated sesquiterpene $\mathrm{C}_{15} \mathrm{H}_{24} \mathrm{O} \mathrm{MW}=220$ & 1607 & - & 0.40 \\
\hline 36 & oxigenated sesquiterpene $\mathrm{C}_{15} \mathrm{H}_{26} \mathrm{O} \mathrm{MW}=222$ & 1625 & - & 0.73 \\
\hline 37 & oxigenated sesquiterpene $\mathrm{C}_{15} \mathrm{H}_{24} \mathrm{O} \mathrm{MW}=220$ & 1629 & - & 1.01 \\
\hline 38 & oxigenated sesquiterpene $\mathrm{C}_{15} \mathrm{H}_{26} \mathrm{O} \mathrm{MW}=222$ & 1646 & - & 0.65 \\
\hline 39 & unidentified $\mathrm{C}_{15} \mathrm{H}_{26} \mathrm{O}_{2} \mathrm{MW}=238$ & 1679 & - & 0.65 \\
\hline \multirow[t]{5}{*}{40} & unidentified $\mathrm{C}_{15} \mathrm{H}_{26} \mathrm{O}_{2} \mathrm{MW}=238$ & 1743 & - & 4.46 \\
\hline & Total monoterpenes & & & 81.80 \\
\hline & Total sesquiterpenes & & & 7.25 \\
\hline & Others & & & 5.31 \\
\hline & Total & & & 94.36 \\
\hline
\end{tabular}

$\mathrm{RI}^{\mathrm{a}}$ : Retention Indices from literature data [17]. $\mathrm{RI}^{\mathrm{b}}$ : Retention Indices calculated by GC/MS using n-alkane series (from $C_{6}$ to $C_{32}$ ) under the same analytical conditions as for the samples.

\subsection{Qualitative Analysis of the Methanol Extract}

The phenolic compounds were characterized according to their UV, HPLC, retention times, mass spectra, and comparison with authentic standards when available. Table 3 shows the chemical composition of the methanolic extract of $A$. moschata. 
Table 3. Summary of phenolic compounds identified in the methanolic extract from A. moschata.

\begin{tabular}{|c|c|c|c|c|}
\hline $\mathbf{R}_{t}(\min )$ & Name & $\mathrm{UV}\left(\lambda_{\max }, \mathrm{nm}\right)$ & {$[\mathbf{M}-\mathbf{H}]^{-}(m / z)$} & ESI-MS/MS (\%) \\
\hline 13.12 & 5-O-Caffeoylquinic acid & $250 ; 299.0(\mathrm{sh}) ; 325.7$ & 353 & $\begin{array}{l}190.7(100)[(\mathrm{M}-\mathrm{H})-162]^{-} \\
178.7(27)[(\mathrm{M}-\mathrm{H})-174]^{-}\end{array}$ \\
\hline 23.46 & 7-O- $\beta$-Glucosyl luteolin & $255.5 ; 267.4(\mathrm{sh}) ; 349.7$ & 447 & $284.8(100)[(\mathrm{M}-\mathrm{H})-162]^{-},{\text {[Aglycone }-\mathrm{H}]^{-}}^{-}$ \\
\hline 31.00 & 7-O- $\beta$-Glucosyl apigenin & $266.2 ; 334.1$ & 431 & $\begin{array}{l}310.8(3)[(\mathrm{M}-\mathrm{H})-120]^{-} \\
268.8(100)[(\mathrm{M}-\mathrm{H})-162]^{-},{\text {[Aglycone }-\mathrm{H}]^{-}}^{-}\end{array}$ \\
\hline 32.26 & 4,5-O-Dicaffeoylquinic acid & $246.0 ; 298.8 ; 329.3$ & 515 & $\begin{array}{l}352.9(100)[(\mathrm{M}-\mathrm{H})-162]^{-} \\
190.7(13)[(\mathrm{M}-\mathrm{H})-324]^{-} \\
178.7(8)[(\mathrm{M}-\mathrm{H})-162-174]^{-} \\
172.7(4)[(\mathrm{M}-\mathrm{H})-162-162-18]^{-}\end{array}$ \\
\hline 34.38 & 3-O- $\beta$-Glucosyl-kaempferol & $266.2 ; 354.1$ & 447 & $284.8(100)[(\mathrm{M}-\mathrm{H})-162]^{-},{ }^{2}$ Aglycone $\left.-\mathrm{H}\right]^{-}$ \\
\hline 38.60 & Luteolin & $250.0 ; 254.3 ; 299.0(s h) ; 347.7$ & 285 & $\begin{array}{l}356.7(16)[(\mathrm{M}-\mathrm{H})-74]^{-} \\
326.8(100)[(\mathrm{M}-\mathrm{H})-104]^{-} \\
284.7(1)[(\mathrm{M}-\mathrm{H})-146]^{-},[\text {Aglycone }-\mathrm{H}]^{-}\end{array}$ \\
\hline 45.11 & Apigenin & $267.4 ; 299.7(s h) ; 336.5$ & 269 & $\begin{array}{l}310.8(3)[(\mathrm{M}-\mathrm{H})-120]^{-} \\
268.8(100)[(\mathrm{M}-\mathrm{H})-162]^{-},{\text {[Aglycone }-\mathrm{H}]^{-}}^{-}\end{array}$ \\
\hline 45.89 & 3-O- $\beta$-Rutinosyl-isorhamnetin & $258.4 ; 276.1(s h) ; 349.5$ & 623 & $\begin{array}{l}314.8(100)[(\mathrm{M}-\mathrm{H})-162-146]^{-},[\text {Aglycone }-\mathrm{H}]^{-} \\
299.8(29)[(\text { Aglycone }-\mathrm{H})-15]^{-}\end{array}$ \\
\hline 47.79 & 3-O- $\beta$-Glucosyl-isorhamnetin & $255.5 ; 275.7(s h) ; 349.7$ & 477 & $\begin{array}{l}314.8(100)[(\mathrm{M}-\mathrm{H})-162]^{-},{\text {[Aglycone }-\mathrm{H}]^{-}} \\
299.9(23)[(\text { Aglycone }-\mathrm{H})-15]^{-}\end{array}$ \\
\hline
\end{tabular}


TLC analyses showed several spots of different colors that were indicative of a complex metabolic profile. A typical intense fluorescence under UV-365 nm was observed immediately after spraying with NP/PEG reagent. As reported in literature [18], the fluorescence behavior is structure-dependent. In particular, flavonols such as glycosides of kaempferol and isorhamnetin give yellow-green fluorescence; flavones such as glycosides of luteolin give an orange color, while glycosides of apigenin produce yellow-green fluorescence and phenolic carboxylic acids appear as intense light blue zones. Taking into account the above reported considerations, we concluded that flavonols and phenolic acids were present in the extract flavones. TLC analyses of the two polar extracts obtained by sonification and Soxhlet (see MM) showed a superimposable profile.

These preliminary data were confirmed by ESI-MS/MS analyses. Spectra of constituents of A. moschata extract showed different fragmentation patterns, suggesting the presence of flavonoids and phenolic acids. In particular, flavonoids had characteristic fragmentation patterns as follows: (a) components which showed the loss of an hexose sugar from the parent ion with a base peak corresponding to the aglycone, suggesting the presence of $O$-glycosylated flavonoids; (b) components with fragment ions $[(\mathrm{M}-\mathrm{H})-104]^{-} ;[(\mathrm{M}-\mathrm{H})-146]^{-}$or [aglycone +83$]^{-}$, in agreement with the presence of deoxyhexose derivatives.

In addition, it was possible to confirm a pattern of fragmentation typical of caffeic acid derivatives: fragments ions at $m / z 173$ or 191 consistent with quinic acid moieties of mono-acyl or di-acyl chlorogenic acids, and fragment ions at $\mathrm{m} / \mathrm{z} 179$ characteristic of a caffeoyl substituent.

This information was supported by UV-data. The UV spectra showed typical behavior of flavonoids and caffeic acid derivatives. The first metabolites exhibited two major absorption bands: band I absorption in the 330-350 $\mathrm{nm}$ range due to the B-ring cynnamoyl system with weak absorption (sh) around $299 \mathrm{~nm}$; band II in the range $240-280 \mathrm{~nm}$ due to A-ring benzoyl system for flavone derivatives while flavonols showed band II in the range $250-270 \mathrm{~nm}$ and band I in the range 350-390 nm.

Compounds with absorption ranges at $325.7-329.3 \mathrm{~nm}$ and $246.1-250.0 \mathrm{~nm}$ plus a diagnostic sharp shoulder at $290-300 \mathrm{~nm}$ were unequivocally identified as chlorogenic acids.

Two groups of major flavones were detected: a group with a band II having two absorption maxima or one maximum with a shoulder (in the range of $250-265 \mathrm{~nm}$ ) —similar to luteolin $\left(3^{\prime}, 4^{\prime}, 5\right.$, 7-tetrahydroxyflavone) derivatives - and another group with a maximum absorption corresponding to the apigenin $\left(4^{\prime}, 5,7\right.$-trihydroxyflavone) derivatives. Moreover, the UV spectra of the extracts showed the presence of flavonols.

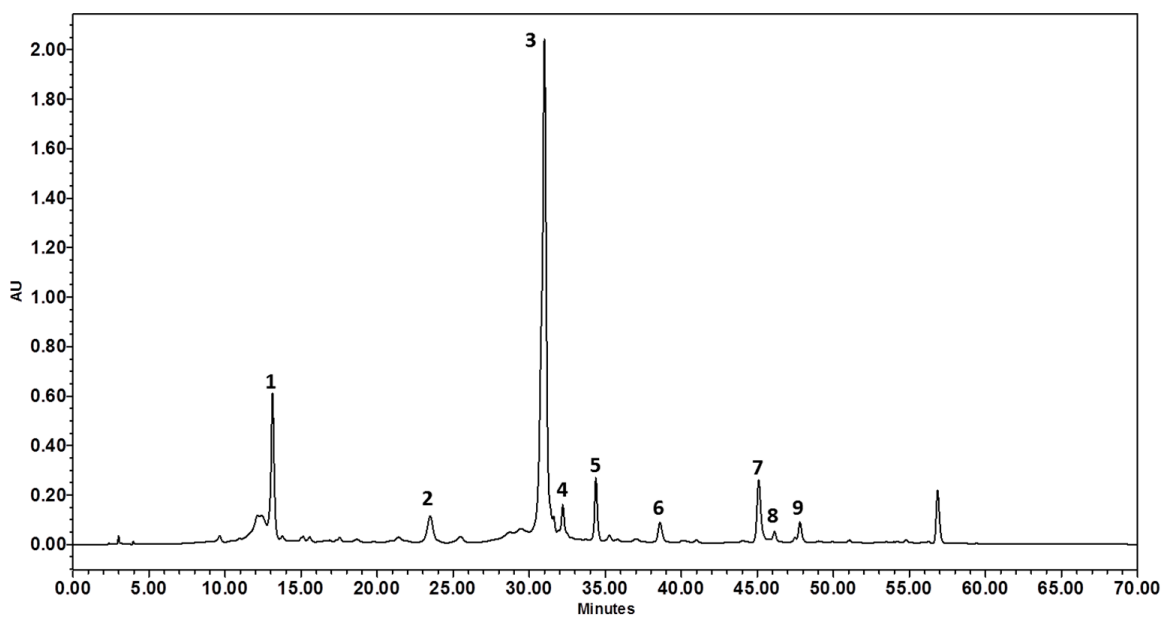

Figure 1. HPLC chromatogram $(310 \mathrm{~nm})$ of $A$. moschata methanolic extract: (1) 5-O-caffeoylquinic acid; (2) 7-O-glucosyl luteolin; (3) 7-O-glucosyl apigenin; (4) 4,5 dicaffeoylquinic acid; (5) 3-O-glucosyl kaempferol; (6) luteolin; (7) apigenin; (8) 3-O-rutinosyl isorhamnetin; (9) 3-O-glucosyl isorhamnetin. 
The sample showed the presence of a prevalent compound (peak 3, Figure 1) with a UV spectrum typical of the apigenin derivatives. This compound was also isolated by HPLC and analyzed by ESI-MS/MS. The MS spectra showed a pseudomolecular ion at $m / z 431$ and the MS 2 revealed the loss of one hexose unit and the appearance of the aglycone fragment at $\mathrm{m} / z 269$ (100) $[(\mathrm{M}-\mathrm{H})-162]^{-}$(apigenin), due to the cleavage at the glycosidic-O-linkage. The metabolite was identified as $7-O-\beta$-glucosyl apigenin. This result was confirmed by comparison between the retention time of the samples and the reference compound.

Peak 1 showed a UV spectra characterized by absorption at $250.0 \mathrm{~nm}, 325.7 \mathrm{~nm}$ and a shoulder peak at $299.0 \mathrm{~nm}$. This UV spectrum is typical of phenolic compounds. The MS spectrum of this compound was characterized by a marker fragment at $\mathrm{m} / \mathrm{z} 191$ due to loss of a caffeic moiety (162 Da). Peak 1 was unambiguously identified as 5-O-caffeoylquinic acid by comparing its retention time with that of a commercial standard.

The HPLC profile of $A$. moschata presented another phenolic compound such as the peak $4\left([\mathrm{M}-\mathrm{H}]^{-}\right.$at $\left.m / z 515\right)$ corresponding to a dicaffeoylquinic acid. This compound was identified as 4,5-O-dicaffeoylquinic acid according to the retention time of the reference standard and the $\mathrm{MS}^{2}$ spectra. $\mathrm{MS}^{2}$ fragmentation was identical to the one previously reported by Clifford et al. [19] and Carbonara et al. [20].

Other flavones were identified in the extract, most of them associated to apigenin and luteolin derivatives based on their UV spectra $\left(\lambda_{\max } 330-350 \mathrm{~nm}\right)$ and $\mathrm{MS}^{2}$ fragmentation pattern. Luteolin-7-O-glucoside (peak 2) was positively identified according to the retention time, mass, and UV spectra similar to that of reference compound.

In addition, the extract was characterized by the presence of free aglycones. Peak $6\left([\mathrm{M}-\mathrm{H}]^{-}\right.$at $m / z 285$ ) isolated by HPLC and analyzed by ESI-MS/MS analysis was identified as luteolin; peak 7 $\left([\mathrm{M}-\mathrm{H}]^{-}\right.$at $\left.m / z 269\right)$ was identified as apigenin based on the retention time, mass, and UV spectra compared with a reference compound.

The remaining phenolic compounds in the extract corresponded to flavonols derivatives, most of them derived from kaempferol ( $\lambda_{\max }$ around $354 \mathrm{~nm}$ and $\mathrm{MS}^{2}$ fragment at $\mathrm{m} / z$ 285) and isorhamnetin ( $\lambda_{\max } 349$ band I and $255 \mathrm{~nm}$ band II and MS ${ }^{2}$ fragment at $\mathrm{m} / \mathrm{z}$ 315). The UV absorptions (Table 3 ) of peak 5 were consistent with a kaempferol derivative. This was supported by ESI-MS/MS analysis, which gave a pseudomolecular ion $[\mathrm{M}-\mathrm{H}]^{-}$at $\mathrm{m} / \mathrm{z} 447$ that fragmented giving only the ion at $m / z 284.8(100)[(\mathrm{M}-\mathrm{H})-162]^{-}$or [aglycone (kaempferol) $\left.-\mathrm{H}\right]^{-}$. Peak 5 was then identified as 3-O- $\beta$-glucosyl kaempferol.

Peak 8 at $\mathrm{m} / \mathrm{z} 623$ could be assigned to the isorhamnetin rutinoside based on the loss of dehoxyhexosyl and hexosyl residue $(146+162 \mathrm{u})$ to yield the aglycone $(\mathrm{m} / \mathrm{z}$ at 315$)$. Based on its fragmentation and UV spectra, peak 9 was instead identified as 3-O- $\beta$-glucosyl isorhamnetin. ESI-MS/MS gave a pseudomolecular ion at $m / z 477[\mathrm{M}-\mathrm{H}]^{-}$which fragmented giving a base peak at $m / z 314.8(100)[(\mathrm{M}-\mathrm{H})-162]^{-}$and less intense fragments at $m / z 461.9(4)[(\mathrm{M}-\mathrm{H})-15]^{-}, 356.9(3)$ $[(\mathrm{M}-\mathrm{H})-120]^{-}$and $299.9(23)$ [Aglycone - 15].

\subsection{Quantitative Analysis of the Methanol Extract}

As shown in Table 4 and Figure 1,7-O- $\beta$-glucosyl apigenin was the predominant compound $(33.57 \mu \mathrm{g} / \mathrm{mg} \cdot \mathrm{dw})$ in the A. moschata methanolic extract followed by 5 -O-caffeoylquinic acid $(10.15 \mu \mathrm{g} / \mathrm{mg} \cdot \mathrm{dw})$. The other components-7-O- $\beta$-glucosyl luteolin, 4,5-O-dicaffeoylquinic acid, 3-O- $\beta$-glucosyl kaempferol, luteolin, 3-O- $\beta$-glucosyl isorhamnetin, and 3-O- $\beta$-rutinosyl isorhamnetin-were present in comparable amounts. Finally, flavonoidic compounds were predominant compared to the caffeic acid derivatives.

The chemical composition of $A$. moschata, shown for the first time in this study, confirmed the trend that was also reported by previous investigations on chemical constituents of the genus Achillea identifying phenolics among the most abundant compound classes [21]. In particular, flavonoids as flavones and flavonols and their derivatives are present, in addition to hydroxycinnamic acids [22]. 
Table 4. Quantification results for phenolic compounds in the methanolic extract from A. moschata.

\begin{tabular}{ccc}
\hline Peak No & Name & $\mu \mathrm{g} / \mathbf{m g} \cdot \mathbf{d w}$ \\
\hline 1 & 5-O-caffeoylquinic acid & $10.15 \pm 0.19$ \\
2 & 7-O-glucosyl luteolin & $2.20 \pm 0.06$ \\
3 & 7-O- $\beta$-glucosyl apigenin & $33.57 \pm 0.93$ \\
4 & 4,5-dicaffeoylquinic acid & $2.53 \pm 0.18$ \\
5 & 3-O- $\beta$-glucosyl-kaempferol & $3.43 \pm 0.05$ \\
6 & Luteolin & $1.10 \pm 0.25$ \\
7 & Apigenin & $3.43 \pm 0.02$ \\
8 & 3-O- $\beta$-Rutinosyl-isorhamnetin & $1.27 \pm 0.10$ \\
9 & 3-O- $\beta$-Glucosyl-isorhamnetin & $3.29 \pm 0.04$ \\
& Total Caffeic compounds & 12.68 \\
Total Flavonoidic compounds & 48.29 \\
\hline
\end{tabular}

A. moschata, like other Achillea species, had apigenin and luteolin as free flavonoid aglycones and, in some cases, also their monoglycosides. However, many differences were present, both in relation to the type and to the amount of compounds [21-25]. For example, in comparison with A. millefolium, the unique species present in the European Pharmacopeia, $A$. moschata showed a different phenolic profile of the methanolic extract. Flavonoids were the major phenolic constituents in A. moschata with 7-O- $\beta$-glucosyl apigenin being the most abundant one, which differs from A. millefolium in which phenolic acids are the major metabolites. $C$ is and trans 3.5-O-dicaffeoylquinic acids predominated in A. millefolium [26,27], while 5-O-caffeoylquinic acid in A. moschata.

Therefore, from a phytochemical point of view, several Achillea species were investigated and a wide diversity was found. With regards to the phenolic compounds, the reason for such variations may be explained by the role that they play as protective agents against oxidative stress related to climatic conditions and geographical distribution. It is known that type, content and proportion of the bioactive substances synthesized by the plants may vary depending on ecological factors including the annual average precipitation, temperature, frost-free period, soil $\mathrm{pH}$, and organic matter [28].

\subsection{Antioxidant Activity}

The antioxidant activity of three extracts with increasing polarity-petroleum ether (PET), dichloromethane (DCM), methanol $(\mathrm{MeOH})$ - and of the essential oil (EO) from A. moschata was assessed by employing ABTS. + (2,2'-azino-bis(3-ethylbenzothiazoline-6-sulfonic acid) and DPPH. (2,2-diphenyl-picryl hydrazyl) radical scavenging assays. A good correlation between the two methods was observed and the results are reported in Table 5. Among the extracts, the only sample showing values useful to calculate $\mathrm{IC}_{50}$ was the $\mathrm{MeOH}$ extract. Its scavenging ability against the DPPH stable radical was higher than that of the reference compound, i.e., quercetin, in agreement with previous data from another population of $A$. moschata [29]. PET and DCM extracts had values of DPPH-scavenging lower than 50\% (Table 5). Similarly, in the ABTS assay, the $\mathrm{MeOH}$ extract exhibited a high degree of activity, 6- and 10-fold stronger than DCM and PET extracts, respectively (Table 5). The negligible radical inhibition of the latter extracts was due to the different solvent polarity, which influences the ability to dissolve the antioxidant compounds, as widely reported [30]. The EO was able to scavenge $\mathrm{DPPH}$ - free radical less effectively than the $\mathrm{MeOH}$ extract, though with $\mathrm{IC}_{50}$ values still significant. Instead, the EO antiradical capacity was weak when it was tested toward ABTS. + (Table 5). There are no previous data on the antioxidant activity of $A$. moschata essential oil. 
Table 5. In vitro antioxidant activity of the extracts and essential oil from aerial parts of $A$. moschata measured by DPPH. and ABTS. + radical scavenging assays.

\begin{tabular}{ccc}
\hline Samples $^{*}$ & DPPH $\left(\mathrm{IC}_{\mathbf{5 0}}\right) \boldsymbol{\mu M}$ & ABTS $(\boldsymbol{\mu m o l} \cdot \mathbf{e q} \cdot$ Trolox/g) \\
\hline $\mathrm{MeOH}$ & $3.18 \pm 0.09$ & $502.44 \pm 0.01$ \\
$\mathrm{DCM}$ & $\mathrm{n} / \mathrm{a}$ & $88.47 \pm 0.01$ \\
$\mathrm{PET}$ & $\mathrm{n} / \mathrm{a}$ & $48.39 \pm 0.01$ \\
$\mathrm{EO}$ & $47.70 \pm 0.78$ & $5.88 \pm 0.01$ \\
Quercetin & $4.39 \pm 0.12$ & -
\end{tabular}

* $\mathrm{MeOH}$, methanol extract; DCM, dichloromethane extract; PET, petroleum ether extract; EO, essential oil. Tests were performed in triplicate; means $\pm \mathrm{SD}$.

On the contrary, there are evidences to support the possible relationship between antioxidant activity and cytotoxicity. During the latest 20 years, the mechanism by which continued oxidative stress can lead to chronic inflammation - which could in turn mediate various diseases including cancer-was revealed [31]. Moreover, experimental studies (both in vitro and in vivo), demonstrated the role of plant natural compounds on growth inhibition of cancer cells [31-34]. Cytotoxic effects were also ascribed to the phenolics whose biological functions are, however, related to their structure. Compounds such as apigenin and luteolin, present in $A$. moschata, exert significant action towards specific cancer cells, while other compounds such as 7-O- $\beta$-glucosyl apigenin, the most abundant, were not investigated from this point of view [34,35]. Therefore, $A$. moschata could be an important cytotoxic species, also considering the strong antioxidant capacity of its methanol extract. Until now, several Achillea species with high antioxidant potential were tested in vitro against different tumor cell lines. They showed variable results depending on the metabolic profile of the crude extract or of the essential oil and their concentration, as well as the type of tumor cell line [22,36-38].

\subsection{Antimicrobial Activity}

The $\mathrm{MeOH}, \mathrm{DCM}$, and PET extracts from the aerial parts and the distilled EO from A. moschata were assayed for their in vitro antimicrobial properties using disk diffusion method [39]. All samples were tested against strains having a particular significance for pathogenesis, drug-resistance, and nosocomial outbreaks [40,41]. Three Gram-positive (Bacillus cereus, Enterococcus faecalis, Staphylococcus aureus) and three Gram-negative (Escherichia coli, Proteus mirabilis, Pseudomonas aeruginosa) that grow aerobically have been chosen. Moreover, we have also considered that the herb A. moschata is used in several remedies such as gastrointestinal disorders, skin inflammations, urinary tract inflammations, infectious diseases (see Table 1) that can be caused by these bacteria. For instance, the food-borne pathogen B. cereus or bacteria that are often isolated from patients with urinary tract infections-E. faecalis, E. coli, P. mirabilis, P. aeruginosa-and the multidrug-resistant S. aureus (MRSA) which causes invasive infections. The growth inhibition diameters of the tested samples are displayed in Table 6.

Table 6. Growth inhibition diameters $(\mathrm{mm})$ against bacterial strains recorded for $\mathrm{MeOH}$ *, DCM, PET extracts and $\mathrm{EO}$ from the aerial parts of $A$. moschata.

\begin{tabular}{ccccc}
\hline Bacteria & MeOH & DCM & PET & EO \\
\hline B. cereus & 8 & 15 & 10 & 24 \\
E. faecalis & - & 11 & 11 & - \\
S. aureus & 8 & 12 & 15 & 18 \\
E. coli & - & - & 13 & 11 \\
P. mirabilis & - & 10 & 15 & 13 \\
P. aeruginosa & - & 8 & 8 & 10 \\
\hline
\end{tabular}

* $\mathrm{MeOH}$, methanol extract; DCM, dichloromethane extract; PET, petroleum ether extract; EO, essential oil. The values represent the mean of inhibition zone diameters (including disk diameter of $6 \mathrm{~mm}$ ). For all values the standard deviation is $<1 \mathrm{~mm}$. 
In contrast of the results of the antiradical capacity, the antimicrobial activity of the extracts was inversely proportional to their increasing polarity of the solvent used for their extraction. The $\mathrm{MeOH}$ extract showed a low inhibitory activity and only against Bacillus cereus (8 $\mathrm{mm})$ and Staphylococcus aureus ( $8 \mathrm{~mm}$ ). DCM extract was found to be active against five out of six tested bacteria (inactive against Escherichia coli), with inhibition diameters ranging from 8 to $15 \mathrm{~mm}$. PET extract proved to be effective against all tested organisms, with inhibition diameters ranging from 8 to $15 \mathrm{~mm}$.

EO demonstrated a broad spectrum of antimicrobial activity against the tested strains, in some cases greater or similar to the conventional antibiotics (erythromycin and ceftazidime). B. cereus was particularly susceptible, with an inhibition zone of $24 \mathrm{~mm}$, followed by S. aureus (18 $\mathrm{mm})$. The susceptibility of the other test bacteria was less pronounced, but still significant (10-13 mm). Lastly, EO showed no activity against Enterococcus faecalis which turned out to the most resistant among the tested microorganisms.

Disks only impregnated with extraction solvents were used as negative control and showed no inhibition of bacterial growth. The ceftazidime reference disks showed inhibition diameters ranging from 17 to $23 \mathrm{~mm}$ (E. coli, Proteus mirabilis, and Pseudomonas aeruginosa). The erythromycin reference disks showed inhibition diameters ranging from 16 to $20 \mathrm{~mm}$ (B. cereus and S. aureus), while no inhibitory effect was observed against E. faecalis.

No previous data about the antimicrobial activity of $A$. moschata have been reported until now. However, some studies were carried out on other Achillea species. Their polar extracts, in agreement with our results, mostly showed weak or no inhibitory effect against the test microrganisms [42-44]. These findings were also in accordance with those of Sökmen and co-authors [45] who observed no antimicrobial activity in the water soluble part of methanol extract from $A$. biebersteinii, while water-insoluble $\left(\mathrm{CHCl}_{3}\right)$ part characterized by less polar compounds was found to have moderate activity against some tested bacteria. The only sample which was strongly active derived from a plant extract obtained by mixing ether, hexane and $\mathrm{MeOH}(1: 1: 1)$ [46]. The antibacterial properties of EO were probably due to their high content of camphor and 1,8-cineol, whose noticeable antimicrobial potential is known [21] as well as that of borneol [47].

A more detailed comparison of the results is difficult due to the fact that the same type of extract and essential oil may vary in efficacy if obtained from the same species collected in different locations. In fact, soil, altitude, and other environmental factors can influence the type and the levels of antimicrobials synthesized by the plant [48].

\section{Materials and Methods}

\subsection{General}

Standards of flavonoids 7-O- $\beta$-glucosyl luteolin, apigenin, and 7-O- $\beta$-glucosyl apigenin were purchased from Extrasynthese (Genay, France). 5-O-caffeoylquinic acid, HPLC grade water, and acetonitrile were purchased from Sigma-Aldrich (Milan, Italy) and 3,4-O-dicaffeoylquinic acid, 4,5-O-dicaffeoylquinic acid and 3,5-O-dicaffeoylquinic acid were obtained from Phytolab (Vestenbergsgreuth, Germany).

Diethyl ether and a series of authentic reference compounds used for identification of the essential oil components were also purchased from Sigma-Aldrich (Milan, Italy).

\subsection{Plant Material}

The aerial parts of $A$. moschata were collected at the blossom period during the summer 2013, at $2400 \mathrm{~m}$ above sea level in Valle dei Forni (Sondrio province, Italy), on the Rhaetian Alps. A voucher specimen (No. AMSHT 103) was deposited at the Department of Agricultural and Environmental Sciences of the Milan State University (Milan, Italy), after its identification according to Flora d'Italia [3]. 


\subsection{Isolation of Essential Oil}

The air-dried aerial parts $(24 \mathrm{~g})$ of the sample were subjected to steam-distillation for $1 \mathrm{~h}$ in a Clevenger-type apparatus. The distillate was saturated with $\mathrm{NaCl}$, extracted with freshly distilled $\mathrm{Et}_{2} \mathrm{O}(3 \times 100 \mathrm{~mL})$, dried over anhydrous $\mathrm{Na}_{2} \mathrm{SO}_{4}$ and concentrated with a rotary evaporator at $30^{\circ} \mathrm{C}$ to give a pale-blue yellow oil with a yield of $0.81 \%$. The oil was diluted with $\mathrm{Et}_{2} \mathrm{O}$ and then used for gaschromatographic analyses.

\subsection{Analysis of the Essential Oil}

\subsubsection{Gas Chromatography-Flame Ionization Detector (GC/FID)}

GC/FID analyses were carried out using a Perkin Elmer model 8500 GC equipped with a $30 \mathrm{~m} \times 0.32 \mathrm{~mm}$ i.d. Elite-5MS capillary column $(0.32 \mu \mathrm{m}$ film thickness $)$. Samples $(0.5 \mu \mathrm{L})$ were injected in the "split" mode (1:30) with a column temperature programme of $40{ }^{\circ} \mathrm{C}$ for 5 min, then increased to $260{ }^{\circ} \mathrm{C}$ at $4{ }^{\circ} \mathrm{C} / \mathrm{min}$ and finally held at this temperature for $10 \mathrm{~min}$. The injector and the detector were set at 250 and $300{ }^{\circ} \mathrm{C}$, respectively; the carrier gas was He with a head pressure of 12.0 psi.

\subsubsection{Gas Chromatography-Mass Spectrometry (GC/MS)}

GC/MS analyses were carried out using a Perkin Elmer Clarus 500 GC equipped with a Clarus 500 mass spectrometer using the same capillary column and chromatographic conditions as was used for GC/FID analysis. The mass spectra were acquired over 40-500 amu range at $1 \mathrm{scan} / \mathrm{s}$ with ionizing electron energy of $70 \mathrm{eV}$ and the ion source set at $200{ }^{\circ} \mathrm{C}$. The transfer line was set at $280{ }^{\circ} \mathrm{C}$, while the carrier gas was He at $1.0 \mathrm{~mL} / \mathrm{min}$.

\subsection{Identification and Quantitation of the Essential Oil Components}

The identification of the volatile oil components was performed by their Retention Indices (marked as RI in Table 2) and their mass spectra, by comparison with a NIST database mass spectral library [49], as well as with literature data $[17,50]$.

Authentic reference compounds purchased from Sigma-Aldrich were also used. Retention indices were calculated using a $n$-alkane series $\left(\mathrm{C}_{6}-\mathrm{C}_{32}\right)$ under the same GC conditions as for the samples. The relative amounts of individual components of the essential oil were expressed as percent peak area relative to total peak area from the GC/FID analyses of the whole extracts.

\subsection{Extraction and Isolation}

Hydroalcholic extract was obtained from dry aerial parts of $A$. moschata plants. The sample ( $4 \mathrm{~g})$ was extracted twice by sonicator with methanol $80 \%(150 \mathrm{~mL} \times 2)$ for $30 \mathrm{~min}$, and subsequently filtered through a filter paper. The combined hydroalcholic extracts were evaporated at $30{ }^{\circ} \mathrm{C}$ (rotary evaporator) to dryness. The dry extract was re-dissolved in methanol (final concentration $30 \mathrm{mg} / \mathrm{mL}$ ) for phenolic compound identification and quantification. In addition, the sample was extracted with Soxhlet in methanol $(9 \mathrm{~g} \times 3 \mathrm{~h}$ ). To obtain non-polar extracts, aerial parts were also defatted with petroleum ether and successively extracted with dichloromethane (Soxhlet apparatus), then concentrated under reduced pressure (rotary evaporator) to dryness and stored at $4{ }^{\circ} \mathrm{C}$ until analyses.

\subsubsection{TLC}

The preliminary screening of the obtained polar extracts (final concentration $30 \mathrm{mg} / \mathrm{mL}$ ) was performed with TLC (precoated silica gel 60 F254 aluminium plates, Merck, Milan, Italy) eluted with ethylacetate/formic acid/acetic acid/water (100:11:11:27 v/v). Visualization of compounds was obtained with Natural Product-Polyethylenglycol Reagent (NP/PEG, Sigma, Milan, Italy). After spraying, TLC plates were observed under UV-366 nm light. 


\subsubsection{HPLC}

The HPLC analysis was performed on a Waters HPLC 600 Liquid Chromatograph (Milan, Italy) instrument equipped with a photo diode-array detector, DAD 2828 Waters. Data were processed with Empower ${ }^{\mathrm{TM}} 2$ Waters Software. The analyses were running on a Gemini C18 (Phenomenex) column $(250 \times 4.6 \mathrm{~mm}$ i.d.; $5 \mu \mathrm{m}$ particle size). The mobile phase was water containing $0.1 \%(v / v)$ formic acid (A) and acetonitrile with $0.1 \%(v / v)$ of formic acid $(\mathrm{B})$. The linear gradient started from $10 \% \mathrm{~B}$ and reached to $60 \% \mathrm{~B}$ in $60 \mathrm{~min}$. The flow rate was $1 \mathrm{~mL} / \mathrm{min}$. UV spectra of the extract were conventionally recorded at 210, 270, 310 and $350 \mathrm{~nm}$. All analyses were run in triplicate. An aliquot of $20 \mu \mathrm{L}$ of each polar extract was injected for each run. For quantitative analysis, 5 -level calibration curve was obtained by injection of known concentrations $(10-250 \mu \mathrm{g} / \mathrm{mL})$ of different standards compounds: luteolin-6-C-glucoside $\left(\mathrm{y}=44625 \mathrm{x}+119464 ; R^{2}=0.9992\right)$ and 5-O-caffeoylquinic acid $\left(\mathrm{y}=32345 \mathrm{x}-58693 ; R^{2}=0.9999\right)$.

\subsubsection{ESI-MS/MS}

Flow injection MS analyses were performed on a 1100 Series Agilent LC/MSD Trap-System VL. An Agilent Chemstation (LC/MSD TrapSoftware 4.1, Agilent Technologies: Santa Clara, CA, USA, 2002) was used for the acquisition and processing of the data. All analyses were carried out using a ESI ion source in the negative mode with the following settings: capillary voltage, $4000 \mathrm{~V}$; nebulizer gas (N2), $15 \mathrm{psi}$; drying gas (N2), $350^{\circ} \mathrm{C}, 5 \mathrm{~L} / \mathrm{min}$. Full scan spectra were acquired over the range of $100-2200 \mathrm{~m} / \mathrm{z}$ with a scan time of $13,000 \mathrm{~m} / \mathrm{z} / \mathrm{s}$. Automated ESI-MS/MS was performed by isolating the base peaks (molecular ions) using an isolation width of $4.0 \mathrm{~m} / \mathrm{z}$, threshold set at 100 and ion charge control on, with max acquire time set at $300 \mathrm{~ms}$. Different collision energies were conventionally used (1.0, 10 and $30 \mathrm{~V})$ for MS/MS fragmentation. Polar samples were dissolved in $\mathrm{MeOH}$ at the concentration of 20-30 ppm and injected at a flow rate of $10 \mu \mathrm{L} / \mathrm{min}$ (KD Scientific Syringe Pump).

\subsection{Antiradical Activity}

\subsubsection{DPPH· Radical-Scavenging Assay}

The 2,2-diphenyl-picryl hydrazyl (DPPH-) radical-scavenging capacity was performed following Iriti et al. [51], with some modifications. In brief, aliquots of each sample, at five different concentrations (from 1-100 $\mu \mathrm{M}$ ), were added to $0.07 \mathrm{mM} \mathrm{MeOH}$ solution of DPPH. free radical reaching a final volume of $2 \mathrm{~mL}$. After a reaction time of $30 \mathrm{~min}$ in the dark at room temperature, the decrease in absorbance was measured at $517 \mathrm{~nm}$. The $\mathrm{IC}_{50}$ was calculated with Prism ${ }^{\circledR} 4$ (GraphPad Software Inc., La Jolla, CA, USA).

\subsubsection{ABTS. ${ }^{+}$Radical-Scavenging Assay}

The 2,2'-azino-bis(3-ethylbenzothiazoline-6-sulfonic acid) (ABTS. ${ }^{+}$) radical cation-scavenging capacity was determined according to Iriti et al. [51]. The ABTS. ${ }^{+}$radical cation was produced by reacting $7 \mathrm{mM}$ ABTS with $2.45 \mathrm{mM}$ potassium persulfate (final concentration) and maintaining the mixture in the dark at room temperature for at least $6 \mathrm{~h}$ before use. The ABTS. ${ }^{+}$solution was diluted with ethanol to an absorbance of $0.7( \pm 0.02)$ at $734 \mathrm{~nm}$ and equilibrated at $30{ }^{\circ} \mathrm{C}$. Ten $\mu \mathrm{L}$ of each sample, ethanol (negative control) and standard solution of the synthetic antioxidant 6-hydroxy-2,5,7,8-tetramethychroman-2-carboxylic acid (Trolox, positive control) were mixed for $30 \mathrm{~s}$ with one $\mathrm{mL}$ of diluted ABTS. ${ }^{+}$solution. Their absorbance was read at $734 \mathrm{~nm}$, at room temperature, $50 \mathrm{~s}$ after the initial mixing. The results are expressed as Trolox equivalent antioxidant capacity (TEAC, $\mu \mathrm{mol} \cdot$ eq. Trolox $\mathrm{mL}$ ). 


\subsection{Antimicrobial Activity}

The disk diffusion method was used according to the standard protocol of Bauer et al. [39] to assess antibacterial activities both of the investigated plant extracts and the essential oil. The following reference strains were included in the study: three Gram-positive (Bacillus cereus ATCC 999091, Enterococcus faecalis ATCC 29212, and Staphylococcus aureus ATCC 25923) and three Gram-negative (Escherichia coli ATCC 35218, Proteus mirabilis ATCC 12453, and Pseudomonas aeruginosa ATCC 27853). All organisms were maintained in brain-heart infusion (BHI medium Oxoid, Milan, Italy) containing $30 \%(v / v)$ glycerol at $-80^{\circ} \mathrm{C}$. Before testing, the suspensions were transferred in $\mathrm{BHI}$ and overnight bacterial cultures were adjusted to 0.5 McFarland standards to achieve an inoculum of approximately $106 \mathrm{CFU} / \mathrm{mL}$, and individually uniformly spread on Muller Hinton agar (MH, Oxoid, Milano) plates using a sterile swab. Each plate was dried for $15 \mathrm{~min}$ and then used for the sensitivity test. Sterile paper disks, $6 \mathrm{~mm}$ in diameter (Oxoid, Milano), which had previously been impregnated with $10 \mu \mathrm{L}$ of each plant extract (MeOH, DCM, PET) and of the essential oil were dried, and then aseptically placed onto the surface of the inoculated media. Disks impregnated with extraction solvents were used as negative controls and disks with ceftazidime (30 $\mu \mathrm{g})$ and erythromycin $(5 \mu \mathrm{g})$ as references for Gram-negative and Gram-positive bacteria, respectively. After incubation at $37^{\circ} \mathrm{C}$ for $18 \mathrm{~h}$, plates were examined and the inhibition zones around the disks were measured (diameters in $\mathrm{mm}$ ). Tests were repeated three times for each extract/microorganism combination.

\section{Conclusions}

This study reported, for the first time to the best of our knowledge, the characterization of the phenolic content and antibacterial activity of $A$. moschata, in addition to showing the high antiradical ability of the methanolic extract. Moreover, we have integrated the data available about the essential oil composition and we have presented the oil's early results related to its biological activity, which was never investigated before.

Our results, although preliminary, provide evidence to support some of the documented ethnobotanical uses of $A$. moschata that suggest its aerial parts can be considered a good source of bioactive compounds, potentially exploitable in the pharmaceutical field. To this end, future studies will focus on the identification of the antimicrobials in the most effective extracts, in addition to investigating other biological activities.

Acknowledgments: This research was partially supported by 'Consiglio per la Ricerca in Agricoltura e l'Analisi dell'Economia Agraria (CREA)' and by Università degli Studi di Bari Aldo Moro (Progetti di Ricerca di Ateneo to PA).

Author Contributions: S.V. and M.I. designed the study. S.V. collected plant samples. S.V. and P.S. performed antiradical activity assays. M.M., L.V. and C.E.C. performed antimicrobial activity test. A.T. carried out the chemical analysis of the essential oil. P.A. and M.P.A. carried out the chemical analysis of the phenolic components. S.V., M.M., A.T., M.I., P.A. and M.P.A. interpreted the obtained data. S.V., M.M., A.T., P.A. and M.P.A. wrote the manuscript. All authors read and approved the manuscript.

Conflicts of Interest: The authors declare no conflict of interest.

\section{References}

1. Sahin, A.; Kiran, Y.; Arabaci, T.; Turkoglu, I. Karyological notes on eight species of Achillea L. (Asteraceae, Santolinoideae) from Turkey. Bot. J. Linn. Soc. 2006, 151, 573-580. [CrossRef]

2. Saeidnia, S.; Gohari, A.R.; Mokhber-Dezfuli, N.; Kiuchi, F. A review on Phytochemistry and medicinal properties of the genus Achillea. Daru 2011, 19, 173-186. [PubMed]

3. Pignatti, S. Flora d'Italia, 1st ed.; Edagricole: Bologna, Italy, 1982; pp. 77-85.

4. Pedrotti, G.; Bertoldi, V. Nomi Dialettali delle Piante Indigene del Trentino e della Ladinia Dolomitica. Presi in Esame dal Punto di Vista della Botanica, della Linguistica e del Folklore; G. Monauni: Trento, Italy, 1930.

5. Chiovenda-Bensi, C. Piante Medicinali Nell'uso Tradizionale della Valle d'Ossola; Atti Accademia Linguistica di Scienze e Lettere: Genova, Italy, 1955; pp. 32-52. 
6. Chiovenda-Bensi, C. Tradizioni e usi Fitoterapici Popolari. La Valsesia; Atti Accademia Linguistica di Scienze e Lettere: Genova, Italy, 1957; pp. 190-205.

7. Sella, A. Flora Popolare Biellese. Nomi dialettali, Tradizioni e usi Locali; Collana della Fondazione Sella; Dell'Orso: Alessandria, Italy, 1992.

8. Grabherr, G. Biodiversity in the high ranges of the Alps: Ethnobotanical and climate change perspectives. Glob. Environ. Chang. 2009, 19, 167-172. [CrossRef]

9. Abbet, C.; Mayor, R.; Roguet, D.; Spichiger, R.; Hamburger, M.; Potterat, O. Ethnobotanical survey on wild alpine food plants in Lower and Central Valais (Switzerland). J. Ethnopharmacol. 2014, 151, 624-634. [CrossRef] [PubMed]

10. Vitalini, S.; Iriti, M.; Puricelli, C.; Ciuchi, D.; Segale, A.; Fico, G. Traditional knowledge on medicinal and food plants used in Val San Giacomo (Sondrio, Italy)—An alpine ethnobotanical study. J. Ethnopharmacol. 2013, 145, 517-529. [CrossRef] [PubMed]

11. Vitalini, S.; Puricelli, C.; Mikerezi, I.; Iriti, M. Plants, people and traditions: Ethnobotanical survey in the Lombard Stelvio National Park and neighbouring areas (Central Alps, Italy). J. Ethnopharmacol. 2015, 173, 435-458. [CrossRef] [PubMed]

12. Gallmetzer, W.; Florineth, F. Study of the germination behaviour of alpine herbs for revegetation of high altitude areas. Rasen Turf Gazon 1996, 27, 4-18.

13. Valant-Vetschera, K.M.; Wollenweber, E. Exudate flavonoid aglycones in the alpine species of Achillea sect. Ptarmica: Chemosystematics of A. moschata and related species (Compositae-Anthemideae). Biochem. Syst. Ecol. 2001, 29, 149-159. [CrossRef]

14. Schwienbacher, E.; Marcante, S.; Erschbamer, B. Alpine species seed longevity in the soil in relation to seed size and shape-a 5-year burial experiment in the Central Alps. Flora Jena 2010, 205, 19-25. [CrossRef]

15. Duke, J.A. Handbook of Phytochemical Constituents of Gras Herbs and Other Economic Plants; CRC Press: Boca Raton, FL, USA, 1992.

16. Maffei, M.; Chialva, F.; Codignola, A. Essential oils and chromosome numbers from Italian Achillea species. J. Ess. Oil Res. 1989, 1, 57-64. [CrossRef]

17. Adams, R.P. Identification of Essential Oil Components by Gas Chromatography/Mass Spectrometry, 4th ed.; Allured Publishing Corporation: Carol Stream, IL, USA, 2007.

18. Wagner, A.; Bladt, S. Plant Drug Analysis. A Thin Layer Chromatography Atlas, 2nd ed.; Springer: New York, NY, USA, 2001; pp. 195-196.

19. Clifford, M.N.; Knight, S.; Kuhnert, N. Discriminating between the six isomers of dicaffeoylquinic acid by LC-MSn. J. Agric. Food Chem. 2005, 53, 3821-3832. [CrossRef] [PubMed]

20. Carbonara, T.; Pascale, R.; Argentieri, M.P.; Papadia, P.; Fanizzi, F.P.; Villanova, L.; Avato, P. Phytochemical analysis of a herbal tea from Artemisia annua L. J. Pharm. Biomed. Anal. 2012, 62, 79-86. [CrossRef] [PubMed]

21. Si, X.-T.; Zhang, M.-L.; Shi, Q.-W.; Kiyota, H. Chemical constituents of the plants in the genus Achillea. Chem. Biodivers. 2006, 3, 1163-1180.

22. Agar, O.T.; Dikmen, M.; Ozturk, N.; Yilmaz, M.A.; Temel, H.; Turkmenoglu, F.P. Comparative studies on phenolic composition, antioxidant, wound healing and cytotoxic activities of selected Achillea L. species growing in Turkey. Molecules 2015, 20, 17976-18000. [CrossRef] [PubMed]

23. Benedec, D.; Vlae, L.; Oniga, I.; Mot, A.C.; Damian, G.; Hanganu, D.; Duma, M.; Silaghi-Dumitrescu, R. Polyphenolic composition, antioxidant and antibacterial activities for two Romanian subspecies of Achillea distans Waldst. Et Kit. Ex Willd. Molecules 2013, 18, 8725-8739. [CrossRef] [PubMed]

24. Vitalini, S.; Beretta, G.; Iriti, M.; Orsenigo, S.; Basilico, N.; Dall'Acqua, S.; Iorizzi, M.; Fico, G. Phenolic compunds from Achillea millefolium L. and their bioactivity. Acta Biochim. Pol. 2011, 58, 203-209. [PubMed]

25. Gherase, F.; Miron, A.; Zagnat, M.; Hancianu, M.; Stanescu, U.; Grigorescu, E. Phytochemical investigations regarding the flavonoidic compounds of some species belonging to the Achillea millefolium L. group. Rev. Med. Chir. Soc. Med. Nat. Iasi. 2004, 108, 177-180. [PubMed]

26. Dias, M.I.; Barros, L.; Duenas, M.; Pereira, E.; Carvalho, A.M.; Alves, R.C.; Oliveira, M.B.P.P; Santos-Buelga, C.; Ferreira, I.C.F.R. Chemical composition of wild and commercial Achillea millefolium L. and bioactivity of the mathanolic extract, infusion and decoction. Food Chem. 2013, 141, 4152-4160. [PubMed]

27. Benedek, B.; Gjoncaj, N.; Saukel, J.; Kopp, B. Distribution of phenolic compounds in Middleeuropean taxa of the Achillea millefolium L. aggregate. Chem. Biodivers. 2007, 4, 849-857. [CrossRef] [PubMed] 
28. Liu, W.; Liu, J.; Yin, D.; Zhao, X. Influence of ecological factors on the production of active substances in the anti-cancer plant Sinopodophyllum hexandrum (Royle) T.S. Ying. PLoS ONE 2015, 10, e0122981. [CrossRef] [PubMed]

29. Vitalini, S.; Grande, S.; Visioli, F.; Agradi, E.; Fico, G.; Tomè, F. Antioxidant activity of wild plants collected in Valsesia, an alpine region of northern Italy. Phytother. Res. 2006, 20, 576-580. [CrossRef] [PubMed]

30. Barchan, A.; Bakkali, M.; Arakrak, A.; Pagán, R.; Laglaoui, A. The effects of solvent polarity on the phenolic contents and antioxidant activity of three Mentha species extracts. Int. J. Curr. Microbiol. App. Sci. 2014, 3, 399-412.

31. Aboul-Enein, A.M.; Shanab, S.M.M.; Shalaby, E.A.; Zahran, M.M.; Lightfoot, D.A.; El-Shemy, H.A. Cytotoxic and antioxidant properties of active principals isolated from water hyacinth against four cancer cells lines. BMC Complement. Altern. Med. 2014, 14, 397. [CrossRef] [PubMed]

32. Allahghadri, T.; Rasooli, I.; Owlia, P.; Nadooshan, M.J.; Ghazanfari, T.; Taghizadeh, M.; Astaneh, S.D. Antimicrobial property, antioxidant capacity, and cytotoxicity of essential oil from cumin produced in Iran. J. Food Sci. 2010, 75, 54-61. [CrossRef] [PubMed]

33. Dai, J.; Mumper, R.J. Plant phenolics: Extraction, analysis and their antioxidant and anticancer properties. Molecules 2010, 15, 7313-7352. [CrossRef] [PubMed]

34. Sulaiman, G.M.; Hussien, M.M.; Marzoog, T.R.; Awad, H.A. Phenolic content, antioxidant, antimicrobial and cytotoxic activities of ethanolic extract of Salix alba. Am. J. Biochem. Biotechnol. 2013, 9, 41-46. [CrossRef]

35. Chang, H.; Mi, M.; Ling, W.; Zhu, J.; Zhang, O.; Wei, N.; Zhou, Y.; Tang, Y.; Yuan, J. Structurally related cytotoxic effects of flavonoids on human cancer cells in vitro. Arch. Pharm. Res. 2008, 31, 1137-1144. [CrossRef] [PubMed]

36. Cupsor-Löffler, B.; Hajdú, Z.; Réthy, B.; Falkay, G.; Forgo, P.; Hohmann, J. Antiprolifertaive effect of flavonoids and sesquiterpenoids from Achillea millefolium s.l. on cultured human tumour cell lines. Phytother. Res. 2009, 23, 672-676. [CrossRef] [PubMed]

37. Bali, E.B.; Açik, L.; Elçi, P.; Sarper, M.; Avcu, F.; Vural, M. In vitro anti-oxidant, cytotoxic and pro-apoptotic effects of Achillea teretifolia Willd extracts on human prostate cancer cell lines. Pharmacogn. Mag. 2015, 11, S308-S315. [PubMed]

38. Boutennoun, H.; Boussouf, L.; Rawashdeh, A.; Al-Qaoud, K.; Abdelhafez, S.; Kebieche, M.; Madani, K. In vitro cytotoxic and antioxidant activities of henolic components of Algerian Achillea odorata leaves. Arab. J. Chem. 2014. [CrossRef]

39. Bauer, A.W.; Kirby, M.M.; Sherris, J.C.; Truck, M. Antibiotic susceptibility testing by a standardized single disk method. Am. J. Clin. Pathol. 1966, 45, 493-496. [PubMed]

40. Vos, P., Garrity, G., Jones, D., Krieg, N.R., Ludwig, W., Rainey, F.A., Schleifer, K.H., Whitman, W., Eds.; Bergey's Manual of Systematic Bacteriology, 2nd ed.; Springer Science \& Business Media: New York, NY, USA, 2009; Volume 3.

41. Garrity, G., Brenner, D.J., Krieg, N.R., Staley, J.R., Eds.; Bergey's Manual ${ }^{\circledR}$ of Systematic Bacteriology, 2nd ed.; Springer Science \& Business Media: New York, NY, USA, 2005; Volume 2.

42. Barbieri Holetz, F.B.; Pessini, G.L.; Sanches, N.R.; Cortez, D.A.G.; Nakamura, C.V.; Dias Filho, B.P. Screening of some plants used in the Brazilian folk medicine for the treatment of infectious diseases. Mem. Inst. Oswaldo Cruz 2002, 97, 1027-1031. [CrossRef]

43. Ozlem, B.; Gulluce, M.; Sahin, F.; Ozer, H.; Kilic, H.; Ozkan, H.; Sokmen, M.; Ozbek, T. Biological activities of the essential oil and methanol extract of Achillea biebersteinii Afan. (Asteraceae). Turk. J. Biol. 2006, 30, 65-73.

44. Turkmenoglu, F.P.; Agar, O.T.; Akaydin, G.; Hayran, M.; Demirci, B. Characterization of volatile compounds of eleven Achillea species from Turkey and biological activities of essential oil and methanol extract of $A$. hamzaoglui Arabaci \& Budak. Molecules 2015, 20, 11432-11458. [PubMed]

45. Sökmen, A.; Sökmen, M.; Daferera, D.; Polissiou, M.; Candan, F.; Ünlü, M.; Akpulat, H.A. The in vitro antioxidant and antimicrobial activities of the essential oil and methanol extracts of Achillea biebersteini Afan. (Asteraceae.). Phytother. Res. 2004, 18, 451-456. [CrossRef] [PubMed]

46. Stojanović, G.; Radulović, N.; Hashimoto, T.; Palić, R. In vitro antimicrobial activity of extracts of four Achillea species: The composition of Achillea clavennae L. (Asteraceae) extract. J. Ethnopharmacol. 2005, 93, 1-7. [CrossRef] [PubMed]

47. Al-Farhan, K.A.; Warad, I.; Al-Resayes, S.I.; Fouda, M.M.; Ghazzali, M. Synthesis, structural chemistry and antimicrobial activity of $-(-)$ borneol derivative. Centr. Eur. J. Chem. 2010, 8, 1127-1133. [CrossRef] 
48. Barbour, E.K.; Al Sharif, M.; Sagherian, V.K.; Habre, A.N.; Talhouk, R.S.; Talhouk, S.N. Screening of selected indigenous plants of Lebanon for antimicrobial activity. J. Ethnopharmacol. 2004, 101, 185-190. [CrossRef] [PubMed]

49. NIST/EPA/NIH Mass Spectral Database; Version 2.1 Perkin-Elmer Instrument LLC; NIST: Gaithersburg, MD, USA, 2000.

50. Joulain, D.; Konig, W.A. The Atlas of Spectral Data of Sesquiterpene Hydrocarbons; E.B. Verlag: Hamburg, Germany, 1998.

51. Iriti, M.; Vitalini, S.; Apostolides, N.A.; El Beyrouthy, M. Chemical composition and antiradical capacity of essential oils from Lebanese medicinal plants. J. Ess. Oil Res. 2014, 26, 466-472. [CrossRef]

Sample Availability: Samples of the essential oil and the phenolics are available from the authors.

(C) 2016 by the authors; licensee MDPI, Basel, Switzerland. This article is an open access article distributed under the terms and conditions of the Creative Commons Attribution (CC-BY) license (http://creativecommons.org/licenses/by/4.0/). 